\title{
PERILAKU SOSIAL BUDAYA MASYARAKAT PETANI YANG BERTENDENSI MENIMBULKAN SYIRIK DI TENGAH KEHIDUPAN MASYARAKAT CIREBON
}

\author{
Setia Budiyanti \\ Universitas Swadaya Gunung Jati Cirebon \\ Jln. Pemuda No.32, Sunyaragi, Kesambi, Sunyaragi, \\ Kesambi, Kota Cirebon, Jawa Barat 45132 \\ Email: Setiabudiyanti77@gmail.com
}

DOI: $10.29313 /$ tjpi.v7i2.3840

Accepted: July 10th, 2018. Approved: April 9th, 2019. Published: April 9th, 2019

\begin{abstract}
This study aims to reveal in depth, whether sedekah bumi or mapag sri or other not to interfere with the system of aqeedah as Muslims. The results of the research are: (1) General rituals, which are carried out either at certain times or during planting activities, and are carried out on the consideration needed by farmers as needed for prayer every time. This ritual is called tama beleq, and nyajen; (2) Rituals carried out during the preparation of planting and during the maintenance of rice plants include: Mappa dendang, umbal and baritan; (3) Rituals conducted before the rice barvest include; Prepegan, nyiwer, mapag sri, and seren taun; (4) The rituals carried out in planting shallots are: Nyadil; and (5) Rituals performed before harvest and the sugarcane giling period, namely: Kawin tebu, and bancakan or giling parties. All of these activities according to the rules of Islamic aqeedah are classified as acts of shirk and such belief systems can be classified as sins that will never be forgiven.
\end{abstract}

Keywords: Socio-Cultural Behavior, Farming Society, Shirk.

\begin{abstract}
ABSTRAK
Penelitian ini bertujuan mengungkeap secara mendalam, apakah sedekah bumi atau mapag sri atau lainnya ini tidak sampai mengganggu sistem aqidah sebagai umat Islam. Hasil penelitiannya, yaitu: (1) Ritual yang bersifat umum, yaitu dilakukan baik pada saat tertentu atau sepanjang kegiatan penanaman, dan dilakukan atas pertimbangan dibutubkan oleb petani sebagaimana dibutubkannya do'a setiap waktu. Ritual ini disebut tama beleq, dan nyajen; (2) Ritual yang dilakukan pada persiapan menanam dan selama pemelibaraan tanaman padi meliputi: Mappa dendang, umbal, dan baritan; (3) Ritual yang dilakukan menjelang panen padi meliputi; Prepegan, nyiner, mapag sri, dan seren taun; (4) Ritual yang dilakukan dalam menanam bawang merah yaitu: Nyadil; dan (5) Ritual yang dilakukan menjelang panen dan masa giling tebu yaitu: Kawin tebu, dan banjakan atau pesta giling. Seluruh kegiatan tersebut menurut kaidah aqidab Islam tergolong tindakan syirik dan sistem keyakinan seperti itu dapat tergolong dosa yang tidak akan pernah diampuni.
\end{abstract}

Kata Kunci: Perilaku Sosial Budaya, Masyarakat Tani, Syirik. 


\section{PENDAHULUAN}

Kegiatan pertanian yang dilakukan oleh masyarakat di Indonesia, termasuk di wilayah Cirebon, sudah dikenal sejak dahulu. Berbagai komoditas tanaman dikembangkan sejak pemerintahan di Indonesia dilakukan oleh Hindia Belanda. Beberapa tanaman utama yang berkembang dari dulu sampai sa'at ini antara lain tanaman padi, tanaman bawang merah, tanaman tebu, disamping tanaman palawija dan tanaman sayuran. Ketiga jenis tanaman ini termasuk jenis tanaman unggulan dari delapan jenis tanaman yang menjadi tanaman unggulan di wilayah Kabupaten Cirebon.

Atas tuntutan teknis budidaya ini selanjutnya masing-masing petani pengelola, memiliki kebiasaan dan budaya yang spasifik. Budaya petani padi berbeda dengan budaya petani bawang merah, dan keduanya juga berbeda dengan budaya petani tanaman tebu. Perbedaan budaya yang terjadi pada para petani, hanya dipersatukan oleh satu kepentingan bahwa ketiganya merupakan bagian usaha dan sebagai matapencaharian yang harus menguntungkan. Selain atas dasar tujuan usaha, maka berbagai aktivitas petani dipersamakan oleh agama dan keyakinan dalam kehidupannya. Demikian halnya dalam Islam, perilaku masyarakat Islam memiliki kesamaan universal, berlaku umum dan diterima masyarakat. Beberapa perbedaan terjadi dalam kegiatan ritual ibadah maupun kehidupan sosial, disebabkan adanya madzhab atau faktor lingkungan.

Pemeluk Islam di Indonesia sangat besar (hingga tahun 1980 mencapai 88,09\%), termasuk di Cirebon (M. Daud Ali. 1998:5). Perkembangan Islam di Cirebon, mengalami akulturasi secara intensif karena Cirebon sebagai pusat perkembangan kebudayaan, yang ditandai oleh adanya kesultanan dengan keratonnya. Dengan demikian, dalam berbagai hal kegiatan keagamaan, banyak diwarnai oleh ciri-ciri agama lain yang melekat. Oleh sebab itu, bagi para petani secara umum dan khususnya di wilayah Kabupaten Cirebon, sebagian dari masyararakat tampaknya masih memiliki suatu model keyakinan di luar standar agama Islam (ajaran Islam). Di tengah mereka, kekhawatiran atas rusaknya tanaman dan gagal panen, serta harapan untuk mendapatkan hasil panen yang maksimal, masih bergantung pada kekuatan lain selain atas ilmu dan teknologi yang menjadi inovasi dalam bertani. Atas hal tersebut, maka petani melakukan sejumlah ritual keagamaan dengan dalih mewujudkan rasa syukur kepada Tuhan Yang Maha Esa. Tolak bala dan rasa syukur tersebut ada yang dilakukan secara individu dan ada juga yang dilakukan secara bersama-sama. Kegiatan yang dilakukan bersama-sama dan berkembang di berbagai desa umumnya dikatakan Sedekah Bumi atau Mapag Sri.

Berkaitan dengan hal tersebut, maka perlu dilakukan kajian secara mendalam, apakah Sedekah Bumi atau Mapag Sri atau lainnya ini tidak sampai mengganggu sistem aqidah sebagai umat Islam. Apabila Sedekah Bumi atau Mapag Sri ini memiliki keterpautan pada sesuatu kekuatan di luar ke Maha Kuasan Allah swt., maka akan menyebabkan tindakan tersebut tergolong syirik. Adapun tindakan syirik sebagaimana Allah berfirman dalam surat An-Nisa (4:48) "Allah tidak akan mengampuni dosa orang-orang yang menyekutukan Allah. Akan tetapi Allah mengampuni dosa-dosa lainnya kepada siapa saja yang Allab kehendaki. Siapa saja yang menyekutukan Allah, ia benar-benar telah melakukan dosa yang sangat besar".

Bentuk rasa syukur yang paling sederhana, dengan mengucapkan hamdalah. Kita memuji Allah atas apa-apa yang Allah anugrahkan kepada kita. Do'a dapat diucapkan dan boleh dilakukan secara sir (hanya dalam hati). Allah berfirman (Surat Al-Baqarah, 2:86), "Wabai Mubammad, bila hamba-hamba-Ku bertanya kepadamu tentang keberadaan-Ku, maka katakana babwa Aku amat dekat dengan hamba-Ku. Aku kabulkan orang-orang yang memohon kepada-Ku, dengan syarat mereka man memenubi perintah-Ku. 
Mudah-mudahan mereka selamat dari kesesatan". Maka berdo'a kepada Allah, baik atas sebab meminta ataupun menyampaikan rasa syukur, tidak membutuhkan media dan bentuk ritual tertentu, karena Allah itu amat dekat.

Bersyukurlah kepada Allah dan Allah akan menambah nikmat kepadamu. Adapun bersyukur kepada Allah termasuk ritual Islam yang telah diatur metodenya. Pengubahan metode atau pencampur adukan metode ibadah menurut Islam dengan budaya agama selain Islam maka hal itu termasuk menyekutukan Allah. Perhatikan nasihat Lukman kepada anaknya yang dinukil oleh A.M. Saefuddin (1996:157) "Hai anaku, janganlah kamu mempersekutukan Allah, sesunggubnya mempersekutukan Allah adalah benar-benar kezaliman yang besar".

Namun demikian, petani, masyarakat dan pemerintah, senantiasa memandang sejumlah ritual tersebut termasuk kategori ungkapan rasa syukur yang dibenarkan oleh ajaran Islam, dan termasuk budaya yang dibolehkan oleh sistem nilai dalam masyarakat.

Dalam bidang pertanian, budaya berkembang sebagi upaya agar kondisi iklim dapat berpihak sejalan dengan kebutuhan pertanaman. Demikian halnya, dalam budaya pertanian, para petani berharap terhindar dari sejumlah gangguan dan ancaman hama dan penyakit tanaman. Banyak dikalangan petani lalu memanjatkan do'a dan berbagai ritual dilakukan untuk keperluan tersebut. Mereka mengatakan do'a itu ditujukan kepada Tuhan Yang Kuasa, akan tetapi karena mereka sadar bahwa metodenya tidak berstandar Islam, maka mereka katakana kepada "do'a untuk yang di atas".

Secara umum, budaya berkembang menuju aspek-aspek yang semakin memberikan kemudahan dan rasa nyaman. Budaya juga tidak stagnan, karena para intelektual berusaha mencari pembenaran atas apa-apa yang dilakukannya. Mampukah rasionya mengikuti apa-apa yang dijalankannya. Adapun sebagaian orang memandang, apabila sutu tindakan sudah tergolong budaya, maka biarkan saja dan budaya dianggap sebagai Hak Azasi Manusi (HAM) untuk dilakukan ataupun tidak. Hal ini sejalan dengan pendapat para ahli Barat dimana HAM semata-mata bersifat antroposentrik artinya segala sesuatu berpusat pada manusia (Departemen Agama RI. 1998/1999:46).

Di tengah masyarakat pedesaan terjadi bentuk-bentuk ritual agama yang berhubungan dengan kehidupan atau proses mencapai dewasanya manusia, selalu diikuti dengan upacara-upacara (Munandar soelaeman. 1995:83). Dengan demikian, bentuk ritual apapun menjadi bagian sahih dalam kehidupan sosial. Sedangkan kegiatan ritual yang dilengkapi oleh bacaan-bacaan Alqur'an dan do'a, maka dianggap bagian kebajikan Islam.

Permasalahan dalam penelitian ini yaitu: Berapa macam tindakan budaya yang berindikasi syirik yang dilakukan oleh individu maupun kelompok masyarakat tani di wilayah Cirebon? Seperti apa ritual yang sesungguhnya dilakukan, dalam upaya tolak bala dan pencarian barokah dalam usaha tani padi, Bawang Merah, dan Tanaman Tebu di wilayah Kabupaten Cirebon?

\section{METODE PENELITIAN}

Penelitian ini dilaksanakan sejak bulan Februari 2012 sampai bulan Agustus 2012. Adapun tempat penelitian ini meliputi wilayah Kabupaten Cirebon, khususnya di kawasan-kawasan sentra produksi tanaman yang menjadi komoditas utama dalam penelitian. Sentra-sentra tersebut ini yaitu tanaman padi menyebar luas pada wilayah Kecamatan Kapetakan, Gegesik, Kaliwedi, Susukan, Panguragan, Arjawinangun, Suranenggala, Ciwaringin, Palimanan, Klangenan, Dukupuntang, Beber dan Sedong.

Penyebaran tanaman Bawang Merah meliputi wilayah Kecamatan Losari, Babakan, Gebang, Waled, Pabedilan, 
Astanajapura, dan Pangenan. Adapun penyebaran tanaman Tebu meliputi wilayah Kecamatan Lemah Abang, Astana Japura, Sedong, Beber, Greged, Talun, Dukupuntang, dan Palimanan.

Data yang dibutuhkan dalam penelitian ini berupa data sekunder dan data primer. Wawancara untuk mendapatkan data primer dilakukan kepada petani, masyarakat umum, tokoh masyarakat, dan para pihak yang memahmi akan lurusnya aqidah islam. Ulama ini diharapkan kompeten untuk menilai substansi dan bobot sutau acara ritual. Analisis data dilakukan secara deskriptif kualitatif, yaitu suatu teknis yang menjelaskan seluruh proses atas peristiwa ritual yang dilakukan dengan menelaah bagian-bagian isi atau substansi, dimana bobot kegiatan bernilai syirik atau terdapat aspek berupa adanya pandangan suatu kekuatan di luar kekuatan allah SWT, sehingga suatu acara di lauar sunnah nabi, dianggap sebagai bentuk ritual agama.

\section{HASIL PENELITIAN}

\section{Keadaan Umum Wilayah Kabupaten Cirebon}

Wilayah Kabupaten Cirebon merupakan bagian dari wilayah Provinsi Jawa Barat yang terletak di bagian timur dan merupakan batas, sekaligus sebagai pintu gerbang Provinsi Jawa Barat di bagian Utara. Bidang pertanian merupakan sektor utama dan strategis di Kapubaten Cirebon yang menyediakan pangan bagi penduduk sehingga keberadaannya harus didukung dan dikembangkan diperlukan.

Secara umum penggunaan lahan di Kabupaten Cirebon berdasarkan data statistik pertanian (SP Lahan) tahun 2010 terdapat perubahan penggunaan lahan di bandingkan dengan tahun 2009 yaitu adanya pengurangan dari lahan sawah menjadi lahan darat seluas 606 ha atau 1,11\%. Lahan bukan sawah bertambah sebesar 2.441 hektar $16,79 \%$, dan lahan bukan pertanian berkurang seluas 275 hektar atau $(0,97 \%)$.
Secara umum, wilayah Kabupaten Cirebon memiliki tingkat kelayakan yang tinggi untuk berbagai usaha pertanian.

\section{Pertanian Sebagai Matapencaharian}

Kabupaten Cirebon memiliki luas baku lahan sebesar $97.965 \mathrm{Ha}$ yang pada tahun 2010 penggunaannya terdiri dari luas lahan pertanian sebesar 71.182 ha dan lahan bukan pertanian seluas 28.343 ha. Lahan pertanian terdiri dari lahan sawah sebesar $54.203 \mathrm{Ha}$, dan lahan bukan sawah seluas $16.979 \mathrm{Ha}$.

Di dalam Rencana Tata Ruang Wilayah Kabupaten Cirebon Tahun 2011 2031 yang telah di tetapkan dalam Peraturan Daerah Kabupaten Cirebon Nomor 17 Tahun 2011 disebutkan bahwa kawasan peruntukan pertanian terdiri dari Kawasan peruntukan tanaman pangan seluas 40.000 hektar, hortikultura seluas 6.000 hektar, perkebunan seluas 8.000 hektar dan peternakan besar seluas 10 hektar dan peternakan unggas seluas 15 hektar.

Sumber daya lahan pertanian di Kabupaten Cirebon berupa lahan-lahan pertanian yang produktif telah mengalami pengurangan sebagai akibat adanya kawasan pemukiman penduduk, industri, sarana transportasi dan sebagainya yang setiap ahun terus bertambah, pengalihan lahan sawah menjadi lahan bukan sawah dalam tahun 2010 dan perkembangannya sejak tahun 1992.

Struktur perekonomian Kabupaten Cirebon masih didiminasi oleh sektor pertanian. Berdasarkan data dari tahun 2006 sampai dengan 2010 (5 tahun), maka dapat di gambarkan bahwa Kabupaten Cirebon memiliki 5 (lima) komoditi unggulan yaitu : Padi, Bawang merah, Mangga, Tebu dan Itik.

Berikut ini gambaran potensi dan peluang investasi di bidang pertanian, khususnya pada 3 komoditas tanaman: 


\section{Padi}

Luas lahan yang tersedia di Kabupaten Cirebon untuk budidaya Padi yaitu \pm 54.000 hektar, dengan rata-rata luas tanam setiap tahunnya 84.624 hektar (IP rata-rata 200), dengan kapasitas produksi sebesar 480.147 ton/tahun Gabah Kering Giling (GKG). Lokasi andalan adalah Kecamatan Gegesik, Susukan, Kapetakan, Kaliwedi, Dukupuntang, Arjawinangun, Klangenan, Sedong, Ciwaringin, Suranenggala, Palimanan, Panguragan, dan Beber.

\section{Bawang Merah}

Luas tanam potensil Bawang Merah adalah \pm 3.900 hektar dengan kapasitas produksi sebesar 40.000 ton/tahun. Kecamatan andalan yaitu Waled, Losari, Astanajapura, Pabedilan, Babakan, Gebang dan Pangenan.

\section{Tebu}

Luas areal potensial adalah \pm 8.061,239 hektar dengan kapasitas produksi 434.353,001 ton/tahun dengan produksi hablur 141.801.213 ton/tahun. Lokasi potensial yaitu di Kecamatan Astanajapura, Lemahabang, Gebang, Babakan, Pangenan, Waled, Pasaleman, Pabedilan, dan Ciledug. Pola investasi yang diharapkan adalah kemitraan.

\section{Budaya Bertani}

Berdasarkan kegiatan ini, terbangun bentuk-bentuk budaya secara spesifik sesuai dengan aktivitas dan perkembangan tanaman yang diusahakan. Pekerjaan pertanaman padi, bawang merah, dan pertanaman tebu, secara umum dapat dikatakan sama. Namun demikian, beberapa bagian teknis budidaya berbeda sesuai dengan jenisnya.

Padi diusahakan pada petakanpetakan sawah yang disekelilingnya dibatasi oleh guludan. Umumnya tanaman padi ditanam dalam bentuk bibit, kemudian areal persawahan digenangi air, sehingga sistem pengairan menjadi kebutuhan penting. Sistem perawatan tanaman relative sederhana, sehingga setelah pertanaman petani biasanya kurang beraktivitas. Pemupukan dan penyiangan gulma dilakukan pada 2 minggu dan 4 minggu setelah tanam, bertujuan agar tanaman dapat tumbuh subur. Tanaman padi sudah menghasilkan bulir-bulir yang tua pada umur 100 hari dan sudah dapat dipanen.

Bawang merah ditanam pada petakan dengan ukuran $2 \mathrm{~m}$ kali 5-6 $\mathrm{m}$ yang petakannya dibatasi oleh parit-parit berisi air untuk menyiram selama pertanaman. Bawang merah ditanam umbinya, dan dilakukan pemupukan serta penyiangan pada umur 2 dan 4 minggu setelah tanam. Tanaman bawang merah termasuk tanaman sensitive dan rentan terhadap berbagai hama maupun penyakit. Sehingga, apabila tanaman mampu bertahan hingga umur 40 hari, dianggap tanaman sudah melewati masa kritis. Selama pertanaman, bawang merah sangat peka oleh air hujan yang dapat melemparkan bakteri dari tanah dan menempel pada daun, sehingga pada daun timbul bercak-bercak putih dan bisa timbul bolong-bolog.

Adapun tebu ditanam pada larikanlarikan yang dikiri dan kanannya berupa guludan. Guludan tersebut secara bertahap diturunkan dan dijadikan tanah bumbunan. Dalam perkembangannya, maka bagian larikan yang ditanami bibit tebu menjadi guludan, sedangkan tanah guludan menjadi parit-parit diantara pertanaman tebu. Panjang guludan pertanaman, biasanya disesuaikan dengan kondisi sawah atau lahan yang dipergunakan. Banyak sedikitnya kadar gula dalam tebu digunakan analisis atau pengujian nilai rendemen. Rendemen tebu bernilai 8 artinya, dalam batang tebu memiliki kandungan gula sebanyak $8 \%$. Nilai rendemen 8 tergolong jenis tebu yang berkualitas. Panen tanaman tebu dapat 
dilakukan setelah pertanaman berumur 1112 bulan.

\section{Ritualitas Bertendensi Syirik}

\section{Ritual pada Budidaya Padi}

Pada budidaya tanaman padi, terdapat berbagai adat ritual yang dilakukan sejak persiapan pertanaman (pengolahan lahan), selama pemeliharaan tanaman, hingga menjelang panen. Diberbagai daerah ritual ini memiliki nama tersendiri atau tergantung pada bahasa umum yang menjadi bahasa petani yang bersangkutan. Demikian dalam melakukannya, ada yang hanya satu jenis saja dan ada yang beberapa kali dengan jenis ritual yang berbeda-beda.

Berapa jenis ritual yang dilakukan pada waktu awal dan selama pemeliharaan tanaman padi meliputi:

\section{Mapag Sri}

Mapag Sri merupakan ritual sebagai persembahan rasa syukur kepada Tuhan karena alam telah demikian berdamai dan memberikan panen padi. Mapag Sri termasuk yang paling popular dilakukan oleh aparat desa bersama masyarakat. Mapag Sri pada umumnya dilakukan menjelang tanam pada musim pertama pertanaman padi (musim hujan pertama). Panitia penyelenggara bisa oleh pejabat desa atau kelompok tani, dan hanya dengan memberitahukan bahwa pada hari tertentu akan dilaksanakan Mapag Sri, maka pada hari tersebut masyarakat mengikutinya.

Mapag Sri diawali oleh suatu upacara di sekitar desa, kemudian masyarakat berkumpul dengan membawa berbagai makanan (tumpeng), ada yang membawa beras, hasil palawija, maupun sayuran. Seluruh bawaan itu selanjutnya diarak berkeliling kampong dan berakhir di desa kembali dengan memakan makanan yang dibawa dan membagikan bahan makanan mentah lainnya.

Susunan acara Mapag Sri baisanya terdiri atas; Pembukaan oleh petugas yang ditunjuk, sambutan oleh aparat desa, dan biasanya acara dibuka oleh pejabat kecamatan, kemudian diakhiri dengan do'a. $\mathrm{Hal}$ ini dilakukan sebelum mengarak makanan berkeliling kampong. Di beberapa desa, acara Mapag Sri dilakukan selama sehari dan dua malam, sehingga malam pertama digelar pertunjukkan wayangan dengan tujuan menghibur para orang tua. Pada malam kedua dilaksanakan pengajian oleh tetua agama yang ditunjjuk. Nampaknya ritual ini seperti biasa-biasa saja dan hal ini dianggap suatu kolaborasi antara budaya dengan ritual agama Islam.

\section{Mappa Dendang}

Mapag dendang merupakan ritual dimulainya pembajakan sawah sampai dengan waktu panen tiba. Mapag dendang juga meliputi ritual penetapan hari tanam dengan bertanya terlebih dahulu kepada dukun/orang tua.

\section{Umbal}

Umbal merupakan ritual pengusiran hama tikus pada tanaman padi. Umbal dilakukan dengan cara menyimpan bungkusan di pinggir petakan sawah, yang biasanya berisi kembang dan sesaji serta benda-benda lain. Sesajen ini semacam formula khusus yang diminta dari orang pintar.

\section{Baritan}

Baritan merupakan ritual berupa syukuran untuk menjauhkan atau menghilangkan gangguan penyakit pada pertanaman. Pada sa'at menjelang dilaksanakannya panen padi, nama jenisjenis ritualnya berbeda, dengan ritual-ritual selama mempersiapakan pertanaman, walaupun secara teknis kegiatannya ada yang relatif sama, yaitu sebagai berikut:

\section{Prepegan}

Prepegan dilakukan ketika menjelang panen padi. Ritual ini nerupakan tanda bahwa panen akan segera dilakukan 
dan panen secara simbolis oleh pimpinan daerah dan diikuti oleh masyarakat lain.

Nyiwer

Nyiwer merupakan ritual sejenis dilakukan pada saat menjelang panen padi. Nyiwer ini dilakukan agar "Dewi Sri" memberikan hasil panen yang banyak dan memberikan keselamatan kepada orangorang yang melakukan pekerjaannya.

\section{Sedekab bumi / Buar bumi}

Sedekah bumi disebut juga buar bumi, ritual ini merupakan rasa syukur atas panen-panen atau disebut syukuran hasil bumi.

\section{Seren Taun}

Seren taun hampir sama dengan sedekah bumi yaitu merupakan ritual syukuran untuk hasil pertanian yang telah dipanen. Masyarakat yang terlibat adalah masyarakat setempat.

\section{Ritual pada Budidaya Bawang Merah}

Nyadil merupakan ritual syukuran 40 hari pertanaman bawang, menurut kepercayaan petani adalah bentuk rasa syukur kepada Allah swt karena kalau sudah 40 hari bawang yang selamat dianggap sudah berada pada fase pertumbuhan yang aman dari gangguan hama dan penyakit.

\section{Ritual pada Budidaya Tanaman Tebu}

\section{Pemberian Wewangian atau Kemenyan}

Ritual untuk mengusir hama tikus/hama penganggu tanaman secara umum. Ritual ini dilakukan dengan cara menyediakan wewangian atau kemenyan yang disimpan dalam petakan disekitar tanaman. Wewangian dan kemenyan yang diberikan dalam dupa (bakaran api), biasanya dilengkapi dengan do'a-do'a dalam bahasa arab atau dalam bahasa daerah bahkan dalam kalimat bahasa khusus. Pekerjaan ini, dianggap efektif dalam mengusir tikus dan dianggap sukses.

\section{Kawin Tebu}

Ritual Kawin Tebu merupakan persembahan rasa syukur kepada Tuhan karena alam telah demikian berdamai memberikan panen. Pasangan remaja lakilaki dan perempuan dan pasangan tebu jantan (dipola seperti ondel-ondel jantan) dan tebu betina (ditampilkan seperti perempuan) lalu disandingkan. Pasangan penganten remaja dan tebu, kemudian diarak berkeliling bersama masyarakat yang membawa sesajian dan berbagai hasil bumi (padi, beras, jagung, kacang yanah, sayuran, dil) mengikuti jalan yang sudah dipersiapkan. Sebelum berangkat, acara digelar yang diikuti dengan sambutan oleh pejabat pemerintah dan pimpinan pabrik gula, serta diakhiri dengan do'a oleh tokoh agama setempat. Pemberangkatan bisa di lakukan di Balai Desa atau di masjid dan berakhir di lokasi pabrik gula. Ritual ini dilakukan pada saat menjelang panen tebu, menurut petani agar tebu memberikan hasil panen yang banyak, rendemen gula tinggi, dan memberikan keselamatan kepada para petani yang bekerja. Bahkan, gula hasil pengolahan pertama suka dibagikan kepada masyarakat. Oleh masyarakat, ritual kawin tebu sebagai penarik wisatawan karena memberikan keramaian.

\section{Banjakan atau Pesta Giling}

Banjakan atau pesta giling, juga merupakan ritual penganten tebu (kawin tebu) yang dilakukan pada saat proses penggilingan perdana panen tebu. Dalam upacara ritual ini, biasanya banyak melibatkan aparat Perusahaan Pabrik Gula bersama Pejabat Pemerintah Kabupaten Cirebon, beserta petani dan masyarakat umum. Bahkan, dalam acara ini diramaikan 
oleh perdagangan oleh pedagang-pedagang kagetan atau pedagang tumpah.

\section{PEMBAHASAN}

Secara umum, para pelaku ritual terbiasa melakukannya karena beranggapan tindakan tersebut bukan syirik. Mereka menyatakan bahwa yang dilakukan adalah sebagai perwujudan rasa syukur kepada Allah. Sesungguhnya mereka telah mencampur adukan antara yang hak dengan yang batil. Dalam setiap ritual, diyakini sebagai sesuatu yang memiliki nilai luhur, yaitu sesuatu yang berkaitan dengan Yang Maha Agung, yang padahal tidak memiliki dasar sebagai ibadah sebagaimana kaidah pokok dalam ibadah bahwa, "ibadah atan perhambaan manusia kepada sesuatu itu asalnya tidak ada, akan tetapi menjadi ada sejalan dengan yang dilakukan oleh Nabi Mubammad saw beribadah kepada Allah swe'.

Kegiatan masyarakat tani yang bertendensi syirik meliputi kegiatan individu dan kegiatan bersama di tengah masyarakat. Kegiatan pemasangan sesajen secara individu dilakukan setiap waktu sepanjang musim pertanaman selama dianggap diperlukan. Sedanglan kegiatan ritual bersama dilakukan pada waktu-waktu tertentu. Dalam ritual bersama, kegiatan senantiasa dipandu oleh tokoh yang dianggap lebih paham mengenai sesuatu atau lebih memiliki otoritas berhubungan dengan sesuatu.

Dalam ritual-ritual sebagaimana di atas, pada dasarnya mereka (petani dan masyarakat), tidak siap menghadapi cobaan yang datang dari Allah swt. Atas ketidak siapan dan ketidak sabarannya, mereka berusaha mencari perlindungan dengan mencampur adukan permohonannya kepada selain Allah. Hal itu tercermin dari cara mereka, disatu sisi dia berdo'a kepada Allah, sedang disisi lain mereka melakukan metode yang diluar ketentuan sunnah Nabi. Mereka mencari pembenaran melalui ucapan bahwa ini sekedar adat atau tradisi dan bukan agama, akan tetapi mereka berdo'a dengan kalimat-kalimat islami, karena berharap kebaikan dari Allah. Rasa ketakutan manusia sebagaimana Allah firmankan pada Qur'an Surat Al-Baqarah (2:155), "Wahai kaum mukmin, Kami pasti menguji kalian dengan berbagai cobaan yang berupa rasa takut, kelaparan, kekurangan harta, jiwa, dan buah-buahan. Wahai Mubammad, berilah kabar gembira kepada orang-orang yang ikhlas menghadapi ujian".

Kesukaan masyarakat terhadap ritual-ritual pada kegiatan pertanaman, yang dilakukan sejak awal kegiatan pengolahan tanah, memasuki pertanaman, selama pemeliharaan tanaman, hingga panen, telah menjadi kesukaan. Sehingga, mereka senang melakukannya walaupun untuk hal itu mereka harus mengeluarkan biaya. Tentang hal tersebut, Allah berfirman dalam Qur'an Surat Al-Baqarah (2:165), "Ada manusia yang menjadikan selain Allab sebagai Tuban yang mereka sembah. Mereka mencintai tuban-tuban itu seperti mencintai Allah....."

Cobaan-cobaan yang Allah datangkan selama pertanaman, mereka imbangi dengan korbanan-korbanan yang ia sanggupi, akan tetapi merekapun tetap mengharapkan ampunan dari Allah swt. Mereka tidak sanggup menerima ujian sebagaimana ujian yang pernah diterima orang-orang beriman. Firman Allah dalam Qur'an Surat Al-Baqarah (2:214) "Wabai kaum muslim, apakah kalian mengira dapat masuk surge sekedar kalian mengaku beriman, padahal belum datang cobaan kepada kalian seperti cobaan yang telah menimpa orang-orang mukmin sebelum kalian. Orang-orang mukmin ditimpa malapetaka dan berbagai bencana. Mereka digoncang oleh berbagai gangguan orangorang kafir sebingga Rasul dan orang-orang mukmin yang menjadi sababatnya berkata, "Kapankah pertolongan Allab itudatang?'. Wahai kaum muslim, ketahuilah bahwa pertolongan Allah itu telah dekat"

Bagi kita, sesungguhnya tidak jauh dan tidak lama, maka pertolongan Allah itu ada dan menghentikan ujian pada kita. Maka orang-orang yang tidak sabar itu, sesungguhnya mereka telah menyelisihi dan 
amat meragukan terhadao Kuasa Allah, meragukan bahwa hanya hak Allah yang memiliki hak disembah. Pekerjaanpekerjaan itu tergolong mendu'akan Allah, naudzubillahi mindzalik.

\section{KESIMPULAN}

Kegiatan-kegiatan ritual yang dilakukan oleh masyarakat di bidang pertanian, jenis dan sifatnya dapat disimpulkan, bahwa: Ritual yang bersifat umum yaitu dilakukan baik pada sa'at tertentu atau sepanjang kegiatan pertanaman, dan dilakukan atas pertimbangan dibutuhkan oleh petani sebagaimana dibutuhkannya do'a setiap waktu. Ritual ini disebut Tama Beleq, dan Nyajen; Ritual yang dilakukan pada persiapan tanam dan selama pemeliharaan tanaman padi meliputi; Mappa Dendang, Umbal, dan Baritan; Ritual yang dilakukan menjelang panen padi meliputi; Prepegan, Nyiwer, Mapag Sri, dan Seren Taun; Ritual yang dilakukan dalam pertanaman bawang merah yaitu Nyadil; dan Ritual yang dilakukan menjelang panen dan masa giling tebu yaitu Kawin Tebu, dan Banjakan atau Pesta Giling.

Seluruh kegiatan tersebut, menurut kaidah aqidah Islam tergolong tindakan syirik dan sistem keyakinan seperti itu dapat ergolong dosa yang tidak akan pernah diampuni. Hal tersebut menimpa pada pelaku secara langsung dan akan mempengaruhi berbagai pihak yang member simpatik atau terlibat secara material langsung maupun tidak langsung.

\section{DAFTAR PUSTAKA}

A.M. Saefuddin. (1996). Fenomena Kemasyarakatan. Refleksi Cendekiawan Muslim. Yogyakarta: Dinamika.

Departemen Agama RI. (1998/1999). Islam untuk Disiplin Ilmu Hukum, Sosial dan Politik. Jakarta: Direktorat Jenderal Pembinaan Kelembagaan Agama Islam.
Profil Pertanian Kabupaten Cirebon. (2010). Peternakan, dan Kebutanan Kabupaten Cirebon. Dinas Petanian Perkebunan,

Mohammad Daud Ali. (1998). Hukum Islam. Jakarta: PT. RajaGrafindo Persada.

Mohamad Idris Ramulyo. (2004). Asas-asas Hukum Islam. Jakarta: Sinar Grafika.

Munandar Soelaeman. (1995). Ilmu Sosial Dasar. Bandung: P'T. Eresco.

Raharjo. (2004). Pengantar Sosiologi Pedesaan. Bandung: Gadjah Mada University Press.

Soedjatmoko. (1995). Dimansi Manusia Dalam Pembangunan. Jakarta: PT. Pustaka LP3ES Indonesia.

Syahidin, Buchari Alma, Munawar Rahmat, Toto Suryana, dan Aam Abdussalam. (2009). Moral dan Kognisi Islam. Bandung: CV. Alfabeta. 